\title{
Motivational Effects of the Case Method on Chinese ESP Learners
}

\author{
Zhiqiang Yu \\ Guangdong University of Foreign Studies, Guangzhou, China
}

\begin{abstract}
The purpose of the present research is to investigate the motivational effects of the case method on Chinese ESP (English for Specific Purposes) learners. A questionnaire consisting of 23 items was designed and a factor analysis was conducted. Results show that the case method involves four motivational dimensions: extrinsic motivation, intrinsic motivation, competition, and self-efficacy. Our findings include: 1) The case method motivates the Chinese ESP learners both intrinsically and extrinsically; 2) The competition factor was found to have a substantial impact on Chinese ESP learners' motivation; and 3) The case method is likely to maximize the Chinese ESP learners' self-efficacy.
\end{abstract}

Index Terms - English for Specific Purposes, case method, competition, self-efficacy, L2 motivation

\section{INTRODUCTION}

According to the latest Guidelines on College English Teaching released by China's Ministry of Education, "the instrumentality of college English is mainly represented / manifested by ESP (English for Specific Purposes)" (Wang 2016). In China, ESP learners are usually non-English majors in universities specializing in such disciplines as technology, engineering, business, management, law, etc. or students and adult learners at a tertiary level institution educating skilled workers. Integrating ESP programs into college English curriculum is to help "meet the national strategic goals of cultivating talents with global vision and leaders well versed in international affairs and regimes" (Ji 2017). To assess the academic achievement of a specific discipline and the success of a higher education institute in terms of 'internationalization' which is being strongly promoted by China, both the Department of Social Sciences at the Ministry of Education and the Office of Academic Affairs at the State Council will put a stress on the number of research papers and articles published in journals indexed by SSCI and A\&HCI (Chen 2014). As a result, an increasing number of Chinese universities start to encourage publications in influential international journals by rewarding the authors with a cash prize, which in turn intensifies the nationwide efforts in higher educational institutions to extend the education of ESP and its sub-categories such as EAP and even ERP (English for Research Publication Purposes).

The embrace of ESP programs is also substantiated by the prevailing worry of 'commencement is unemployment'. To ensure that they gain an advantage in China's intensely competitive job market after graduation, the undergraduates are crazy about getting certificates of English levels as their English proficiency, usually perceived as 'a stepping-stone to success', will increase the chances of getting a job interview while meeting other requirements. A popular coinage is the 'Certificate Motivation' (Hua 1998) which refers to the motives shown by the undergraduates in China to obtain a nationally recognized certificate of English proficiency such as CET4 (College English Test Band 4) or CET6 as a must to graduate, or globally recognized BEC (Business English Certificate) or TOEIC (Test of English for International Communication) to secure a well-paid position in a multinational business company. A recent widely circulated advertising slogan online is 'The level of your income is set by the level of your English', which is frequently used by many private commercial English language education providers in China to attract adult learners in the workforce.

As a result of the booming ESP programs, an increasing number of Chinese universities are introducing case studies into the ESP classrooms. The case method was initiated at the Harvard Business School at the beginning of the $20^{\text {th }}$ century, where it was considered as a problem-based instruction drawing on real-life situations (Merseth 1991). According to Kurz et al. (2005), the case method is a teaching approach to bridging the gap between theory and practice by motivating the learners to apply theoretical concepts to real-world situations. A number of studies reveal that problem-based learning environments augment learners' intrinsic interest in the subject matter (Norman \& Schmidt 1992), promote the awareness of taking responsibility for their own learning (Spencer \& Jordan 1999), and enhance students' intrinsic motivation by involving them in authentic assignments (Hmelo-Silver 2004). Shulman (1992) suggests that the effectiveness of the case method instruction is attributed to such potent elements as "narrative nature, situated learning, and cognitive flexibility" (Kurz et. al 2005:67). Although the benefits of the case method are extensively recognized, there has been an underrepresentation of its beneficial aspects for ESP learning in L2 settings.

The present research is an attempt to shed light on the motivational effects of the case method on China's ESP learners. The following research questions will be addressed:

1) How can the case method motivate the Chinese ESP learners both extrinsically and intrinsically?

2) What role can competition play in motivating Chinese ESP learners?

3) How can the case method promote Chinese ESP learners' self-efficacy? 


\section{Motivation In SECOND LANGUAGe ACQUisition}

Dörnyei (2005:65) claims that "motivation provides the primary impetus to initiate L2 learning and later the driving force to sustain the long and often tedious learning process; indeed, all the other factors involved in SLA presuppose motivation to some extent". L2 motivation is such a complex and multi-faceted concept that there has been a variety of theoretical approaches trying to highlight different aspects of this complexity. With the socio-educational model first proposed by Gardner $(1959,1983)$, the alternative theoretical frameworks range from Self-Determination Theory or SDT (Deci \& Ryan 1985) to L2 Motivational Self-System (Dörnyei 2005) and the latest Process Motivation Model (Bower 2014). The present study attempts to examine the motivational effects of the case method on Chinese ESP learners, drawing on SDT as a macro perspective and on Components of Foreign Language Learning Motivation (Dörnyei 1998) as a micro perspective.

\section{A. The Macro Perspective: Self-determination Theory}

SDT is basically a social psychology theory of human motivation. The principal assumption is that if the three basic psychological needs for competence, autonomy, and relatedness are satisfied, individuals will be likely to express their inherent propensity to learn, to do, and to grow (Deci \& Ryan, 1985). Competence refers to the innateness to stretch one's skills and schemata further and the propensities to pursue challenges that are just beyond one's current level of functioning and through such activity to both make developmental gains and derive a sense of confidence and self-esteem (Harter, 1982). Autonomy involves doing things out of one's personal interest or desire and making decisions on one's own to engage in a specific learning activity. In autonomous action, one experiences the self to be an agent, the 'locus of causality' of one's behavior (Ryan \& Connell, 1989). It represents the freedom of choice and is the 'self-rule' which regulates one's own behavior and experience and governs the initiation and direction of action. As suggested by Ushioda (1996:2), "autonomous language learners are by definition motivated learners". Relatedness refers to the social dimension of living organisms which specifically concerns the universal urge or desire for interaction, contact, support, and community with others, involving the 'emotional and personal bonds between individuals'. According to Ryan \& Deci (2000), the three innate psychological needs foster and facilitate intrinsic motivation when satisfied, and undermine motivation and well-being when thwarted.

SDT classifies motivation into two general types: intrinsic motivation (IM) and extrinsic motivation (EM). These seem to be more effective and sensible than Gardner's dichotomy of instrumental and integrative orientations as some researchers challenge the validity of integrative motive (Lukmani 1972, Noels et al. 2003). As pointed out by Lamb (2004, 2013), in the age of globalization, the need to use English to communicate on the global scene has overridden the need to be attracted to the culture or community of English speakers for many users.

According to SDT, IM is based on the innate needs for competence and autonomy. A tripartite taxonomy of IM proposed by Vallerand et al. (1989) involves IM-Knowledge, IM-Accomplishment, and IM-Stimulation. IM is established or operative if one's engagement in an activity is to experience sensory pleasure, fun, excitement, satisfaction, or aesthetic appreciation. The common basis of the subtypes of IM is the pleasant experiences or interest arising from the self-initiated and challenging events (Noels et al. 2003). Good examples are those students who attend the ESP programs to experience the excitement of studying English business cases.

Noels et al. (2003) suggest that much overlap between instrumentally oriented motivation and externally regulated motivation lies in that both concepts imply the behaviors and actions arising from outside the individual and the pursuit of an activity is driven by external rewards and social milieu. As defined by Lambert (1973:14), an instrumental orientation concerns "the practical value and advantages of learning a new language". To be specific, instrumentality has been labelled as the utilitarian dimension that involves better job prospects, travelling, making foreign friends, and even understanding the lyrics of English songs (Csizér \& Dörnyei 2005). In the framework of SDT, EM refers to any learning actions or behaviors carried out to achieve specific instrumental ends. EM does not necessarily imply a lack of self-determination but represents different levels of internalization or regulation (Deci \& Ryan 1985). EM falls into three categories, on the basis of an increasing level of self-determination: external regulation, introjected regulation, and identified regulation (Vallerand et al. 1989). A good example of external regulation is that ESP learners come to study English business cases in order to access better job opportunities.

The conceptualization of IM and EM is very helpful in predicting L2 learning outcomes (Ramage 1990). It is also important to note that extrinsic motivation is no longer considered as negative or seen as the opposite of intrinsic motivation, but rather lying along a continuum of self-determination. The continuum reveals the dynamic process of motivation development by describing the degree of internalization from extrinsic motives to personally endorsed values and self-regulated behaviors. It involves the degree to which individuals fulfill their basic psychological needs. But the problem with SDT lies in the difficulty and confusion involved in assessing the degree of internalization especially concerning the distinction between identified regulation and integrated regulation (Vallerand et al. 1992). According to Williams \& Burden (1997:123), "this distinction (of EM and IM) is not watertight; many of our actions are probably prompted by a mixture of both intrinsic and extrinsic reasons". On the other hand, SDT fails to take into account such factors as the classroom environment, instructional techniques, and the learning situation. Therefore, a micro perspective is necessary to focus on the motivational components of the learning environment, identifying and analyzing classroom-specific motives (Dörnyei 1998). 


\section{B. The Micro Perspective: Components of Foreign Language Learning Motivation}

Based on a careful review of previous motivational theories and models, Dörnyei (1994) proposed a more specific framework of L2 motivation in an attempt to categorize various components into three major dimensions: the Language Level, the Learner Level, and the Learning Situation Level. Of the three levels, components concerning the language learners and the learning situation have been more elaborated and discussed. The Learner Level involves very specific aspects of language anxiety, perceived L2 competence, attribution about past experiences, and self-efficacy. Among all these factors, self-efficacy has been drawing extensive research interest in L2 motivation mainly due to its close association with competence motivation theory.

Dörnyei (1994) suggests that the Learning Situation Level is the most detailed and informative part of the framework. This level of L2 motivation involves intrinsic and extrinsic motives and motivational conditions falling into three categories. 1) Course-specific motivational components are concerned with the syllabus, the teaching materials, the teaching method, and the learning tasks. 2) Teacher-specific motivational components involve the affiliative drive to please the teacher, authority type, modelling, task presentation, and feedback. 3) Group-specific motivational components include goal-orientation, norm and reward system, group cohesion, and classroom goal structure. Among all these, our attention is directed to the "classroom goal structure" which involves the question of whether the classroom is supposed to be competitive, cooperative, or individualistic in terms of learning motivation.

Dörnyei's list of components of foreign language learning motivation provides a highly detailed framework of L2 motivational factors. From this micro perspective of L2 learning motivation, we shall focus on the aspect of self-efficacy at the Learner Level and the competition factor at the Learning Situation Level.

\section{Self-Efficacy as a Motivational Component}

Self-efficacy concerns judging one's own abilities and competence before implementing a task (Bandura 1982). According to Bandura (1994), three theories underpin the self-efficacy concept: attribution theory, expectancy-value theory, and goal theory. First, people with perceived self-efficacy usually attribute their failures to insufficient effort. Secondly, individuals act on their beliefs about the likely outcomes of their performance as well. Thirdly, the strength of self-efficacy determines the goal-setting as people with a strong sense of efficacy will exert greater effort when they fail to master the challenge.

Bandura (1977) identifies four main sources of self-efficacy. 1) Mastery experiences are the most effective way of developing a strong sense of efficacy as development of skills and acquisition of better means build an immediate belief in one's personal efficacy. 2) Social models provide vicarious experiences that strengthen self-beliefs of efficacy. Modeling influences are greatly determined by assumed similarity to the models. The greater the perceived similarity, the more influential the model's performances are. 3) Social persuasion strengthens one's beliefs that he/she has what it takes to succeed. Persuasive boosts lead people to exert best effort and sustain it to succeed. 4) Somatic and emotional states affect the judgment of one's capabilities. To enhance one's self-efficacy, it is necessary to reduce stress reactions and negative emotional and physical states.

There is a strong positive correlation between extended efforts and self-efficacy. According to Ames (1992:262), if learners believe that their intended efforts will lead to a mastery experience or learning success, their sense of efficacy will be promoted by demonstrating willingness and propensity to expend extra efforts and sustain their engagement in the learning process.

\section{Competition as a Motivational Component}

Deci et al. (1981) suggests that competition undermined intrinsic motivation. Their study found that participants who had been in competition against others in an activity were less likely to return during a free-choice period than those who had not competed. The authors interpreted that participants' focus on winning rather than on the activity itself was responsible for the lack of intrinsic motivation. But Franken \& Brown (1995:176) argued that three reasons explain why competitive situations can be a source of motivation. First, competition involves winners and losers. Secondly, competition provides individuals with models or examples to follow, which facilitates mastery of skills. And thirdly, competition supplies "information about what is an acceptable or high level of performance". In other words, competition provides immediate feedback on one's current level of competence and thus increases the mastery of the participant's competence and improves their performance.

As direct competition may involve ego-threatening elements, Tripathi (2001) found that indirect competition carrying competence information resulted in greater intrinsic motivation. Many other studies show that competitive contexts or learning environments can enhance both competence valuation and a sense of challenge or excitement, which consequently promotes individual involvement and intrinsic motivation (Epstein \& Harackiewicz 1992; Harackiewicz \& Manderlink 1984; Tauer \& Harackiewicz 1999).

\section{The Present Study}

The current research attempts to examine the motivational effects of the case method in Chinese ESP programs. From a macro SDT perspective, we hypothesized that the case method used in ESP programs can motivate Chinese learners both extrinsically and intrinsically. Studying business cases in English has the essential instrumental value to the Chinese ESP learners as it concerns such practical skills as critical thinking, problem-solving, and English communication skills. These skills are thought to be highly useful in job seeking due to the fact that they are being 
valued and sought by China's best employers and top head hunters. On the other hand, the case method is featured with constructivism and engaging elements to promote learners' intrinsic motivation and foster an autonomy-supportive learning environment.

From a micro motivational component perspective, we predicted that the case method is likely to create a predominantly indirectly competitive learning situation that provides immediate competence and mastery information to promote learners' intrinsic motivation. It was also predicted that the modeling and mastery experiences involved in the case method enhance the learners' self-efficacy that is likely to contribute to their engagement in the learning activity.

\section{METHOD}

\section{A. Subjects and the ESP Case Method}

A group of 185 business students from a university located in South China participated in the research. They are 100 undergraduates majoring in logistics management from the business school and 85 undergraduates majoring in business law from the law school registered in ESP programs. All the subjects speak Chinese as their mother tongue and they are all in the second year aging from 18 to 20. As required by the university, all the business and law students are to complete the ESP courses designed to enhance their professional English communication skills in an increasingly globalized market. All the subjects have passed the College English Test Band 4 (CET-4) and 56\% of them have gained the higher level of proficiency CET-6. (The CET has been in operation for 30 years in China and now it has become the largest test in the world due to the fact that the annual number of test takers has reached 1.8 million. CET is important for Chinese college students as only CET certification holders can be granted the bachelor's degree and the majority of the export-oriented business companies in China seek applicants with CET certificates.)

Through the whole academic year, the case method had been used in the ESP program to instruct the students on how to analyze business problems, reconcile conflicting viewpoints, justify themselves, and decide on a course of action. The case method involves such advanced skills as critical thinking, problem solving, and decision making. All the cases are originally written by English native authors, mainly concerned with multinational business companies like Wal-Mart, Toyota, Dell, or Facebook etc. By bringing real-life business problems into the classroom and training them to think and decide like managers or lawyers, the instructors facilitate and guide the group discussion in English. After sessions of discussion, a representative from each group will be asked to deliver an English presentation or report. The case method used in ESP programs is a form of content and language integrated learning (CLIL), which involves content-based learning and problem-solving strategies aiming to develop advanced English learners' language communication skills.

\section{B. Instruments}

A questionnaire accommodating the specific features of the case method in ESP programs is designed in Chinese, as an effort to guarantee the full understanding of the specific items on the part of the subjects. The questionnaire consists of 23 questions intended to measure the following four variables:

1) Extrinsic Motivation (8 items), measuring the utilitarian benefits of studying cases in English, such as the competitiveness in job seeking, e.g. "I think studying English cases enhances my competitive edge in the job market." Cronbach's alpha: 0.94 .

2) Intrinsic Motivation (4 items), concerning the interest and enjoyment inherent in the learning activity, e.g. "I think it is great fun to study English cases." Cronbach's alpha: 0. 93.

3) Self-Efficacy (4 items), indicating the learners' beliefs that they have the capabilities to complete the learning tasks involved in studying English cases, e.g. "I think I can identify the key issues in the case." Cronbach's alpha: 0.89.

4) Competition ( 7 items), involving ESP learners' desire to win and their propensity to increase their competence, e.g. "I hope to be the first to figure out a solution.", "I hope to be more insightful than others". Cronbach's alpha: 0.92

\section{Procedures}

A pilot study was conducted prior to the formal survey and some ineffective or confusing items were eliminated, modified or replaced. A statement is made at the top of the questionnaire informing the subjects that their participation is voluntary and all the data being collected would be anonymous and confidential. This is to minimize the respondents' worries or concerns when expressing their real attitudes towards the case method used in ESP classroom and thus to maximize the authenticity of their responses. The questionnaire was then posted and published on a specialized online survey website at the end of the ESP program and the subjects were asked to rate the items on a 7-point Likert scale the degree to which the items were "Totally disagree" to "Totally agree". Most of the respondents completed the questionnaire on their smartphone and data collection was automatically done online. A higher score indicates a higher level of agreement. All the raw data collected online was processed and a factor analysis was conducted by IBM SPSS Statistics 20 .

\section{RESULTS AND DISCUSSION}

\section{A. Exploratory Factor Analysis}


The data were subjected to an exploratory factor analysis and the reliability, validity, and applicability of the motivational factor structure involved in the case method being applied to the Chinese ESP learners were assessed. The detailed results of the exploratory factor analysis of the questionnaire data were presented in the following section.

\section{B. Reliability and Validity}

The results of the KMO and Barlett's Test show that the KMO measure of the sampling adequacy was .937 (> .08), which is believed to be an excellent indicator suggesting that the variables are perfect for an exploratory factor analysis (see Table 1). The p-value (Sig.) of .000 is less than .05, therefore suggesting that the factor analysis is valid. Additionally, the approximate of Chi-square scores 3946.780 with 253 degrees of freedom, further indicating the suitability of the analysis. In the meantime, the Cronbach's Alpha of the four subscales range from 0.940 to 0.893 (see Table 2) with an average of $.92(>0.7)$ which is marvelously high, suggesting that the items in each group are highly correlated and the scale is very reliable. Hence an exploratory factor analysis is considered as an appropriate technique for further analysis of the data.

TABLE 1.

KMO AND BARTLETT'S TEST

\begin{tabular}{|l|l|l|}
\hline \multicolumn{2}{|c|}{ Kaiser-Meyer-Olkin Measure of Sampling Adequacy. } & .937 \\
\hline \multirow{3}{*}{ Bartlett's Test of Sphericity } & Approx. Chi-Square & 3946.780 \\
& df & 253 \\
& Sig. & .000 \\
\hline
\end{tabular}

TABLE 2.

RELIABILITY STATISTICS

\begin{tabular}{|ll|}
\hline Subscales & Cronbach's Alpha \\
1. EM & 0.940 \\
2. Competition & 0.923 \\
3. IM & 0.934 \\
4. Self-efficacy & 0.893 \\
Average & 0.923 \\
\hline
\end{tabular}

TABLE 3.

TOTAL VARIANCE EXPLAINED

\begin{tabular}{|c|c|c|c|c|c|c|}
\hline \multirow[t]{2}{*}{ Component } & \multicolumn{3}{|c|}{ Initial Eigenvalues } & \multicolumn{3}{|c|}{ Rotation Sums of Squared Loadings } \\
\hline & Total & $\%$ of Variance & Cumulative \% & Total & $\%$ of Variance & Cumulative $\%$ \\
\hline 1 & 12.318 & 53.558 & 53.558 & 5.571 & 24.222 & 24.222 \\
\hline 2 & 2.439 & 10.606 & 64.164 & 5.058 & 21.991 & 46.213 \\
\hline 3 & 1.688 & 7.340 & 71.505 & 3.417 & 14.858 & 61.071 \\
\hline 4 & 1.001 & 4.350 & 75.855 & 3.400 & 14.784 & 75.855 \\
\hline 5 & 679 & 2.954 & 78.808 & & & \\
\hline 6 & .594 & 2.583 & 81.392 & & & \\
\hline 7 & .510 & 2.215 & 83.607 & & & \\
\hline 8 & .434 & 1.886 & 85.493 & & & \\
\hline 9 & .393 & 1.710 & 87.203 & & & \\
\hline 10 & .374 & 1.625 & 88.827 & & & \\
\hline 11 & .318 & 1.382 & 90.210 & & & \\
\hline 12 & .308 & 1.338 & 91.548 & & & \\
\hline 13 & .299 & 1.300 & 92.848 & & & \\
\hline 14 & .256 & 1.114 & 93.962 & & & \\
\hline 15 & .230 & .999 & 94.961 & & & \\
\hline 16 & .208 & .903 & 95.864 & & & \\
\hline 17 & .192 & .833 & 96.698 & & & \\
\hline 18 & .158 & .687 & 97.385 & & & \\
\hline 19 & .143 & .620 & 98.005 & & & \\
\hline 20 & .138 & .602 & 98.607 & & & \\
\hline 21 & .118 & .513 & 99.120 & & & \\
\hline 22 & .109 & .475 & 99.594 & & & \\
\hline 23 & .093 & .406 & 100.000 & & & \\
\hline
\end{tabular}

On the basis of Varimax Rotation with Kaiser Normalisation (Table 3), four factors have been extracted (extraction method: Principal Component Analysis). A total number of 23 variables used in the survey were clustered into 4 factors (based on Eigenvalues greater than 1) and each factor consists of all those variables with factor loadings greater than 0.5 . After rotation, Factor 1 accounts for $24.22 \%$ of the total variance, with Factor $221.99 \%$, Factor $314.86 \%$, and Factor 4 $14.78 \%$. The 4 extracted factors have explained $75.86 \%$ of the total variance in the motivational effects of the case method survey, accounting for over $3 / 4$ of the total variance.

\section{Extrinsic Motivation Factor}


The Rotated Component Matrix (Table 4) reveals the factor loadings after an orthogonal rotation. In the factor matrix, the loadings less than 0.53 are removed for the sake of clarity. As illustrated in Table 4, the first factor is named EM (Extrinsic Motivation) which examines the degree of instrumentality in the learning motivation. The factor explains $24.22 \%$ of the total variance. This group consists of 8 items with loadings ranging from 0.83 to 0.64 . Under the factor of EM, the item "I think studying English cases will enhance my competitive edge in the job market" tops the group with the highest loading of 0.83 . The results reveal that the Chinese ESP learners are instrumentally motivated by the benefits of studying cases in terms of employment due to the fact that China has an estimated record-breaking number of 8.34 million graduates from nearly 3000 Chinese universities and colleges in 2019 and college graduates employment has always been one of the government top concerns (Meng 2018). The Chinese premier Li Keqiang pledged in his 2019 government work report that creating enough job opportunities remains the top priority of the government at all levels as the rising unemployment rate undermines the social stability. "The hardest job hunting season in history" is coined and widely circulated on the Internet and social media. In this intensively competitive labor market, the university learners are confronted with unprecedented pressure resulting from securing a job after graduation. Worries are also derived from the mismatch between what is being learned at school and what is sought by employers. The Chinese ESP learners are apparently aware of the absence of such assets as English communication skills and critical thinking in China's exam-oriented educational system, which is explained by the top two means of the items in the group (on a 7-point Likert scale) "I think studying English business cases can promote my English communication skills (5.78)" and "I think studying English business cases can enhance my critical thinking (5.63)". According to the survey conducted by Yue \& Zhou (2017), the top concern of the Chinese university graduates in job seeking is career development prospects and income level. This can be clearly addressed by the items "I think studying English business cases will help my future career development" and "I think studying English business cases will promote my future income level".

The results indicate that the Chinese ESP learners are extrinsically motivated and they are dramatically realistic as a result of the nationwide pragmatic philosophies and concerns about uninviting employment prospects and inadequate skills. In China, Deng Xiaoping's "cat theory" (literally "A good cat catches mice no matter it is yellow or black." and metaphorically "Economic growth is everything regardless of socialism or capitalism.") is interpreted as a nationwide pragmatism mentality (Jing 2017) and has had a far-reaching impact on the social behavior in the densely populated country. Material incentives are believed to be the most effective way to motivate people to work hard and thus help achieve the targets of economic growth. In a country where pragmatic philosophies prevail and the instrumentality of ESP is clearly stated in the Guidelines on College English Teaching, studying business cases in ESP programs is first and foremost perceived as a competitive advantage that conceivably empowers the learners to access the best job opportunities in the highly competitive labor market.

TABLE 4

ROTATED COMPONENT MATRIX

\begin{tabular}{|c|c|c|c|c|c|c|c|}
\hline \multirow[t]{2}{*}{ Variables } & \multicolumn{4}{|c|}{ Component } & \multirow[t]{2}{*}{ Mean } & \multirow[t]{2}{*}{ SD } & \multirow[t]{2}{*}{$\eta 2$} \\
\hline & 1 & 2 & 3 & 4 & & & \\
\hline $\begin{array}{l}\text { Extrinsic Motivation: } \\
\text { Enhancing my competitiveness in the job } \\
\text { market }\end{array}$ & .827 & & & & 5.09 & 1.346 & .820 \\
\hline Expanding my business expertise & .815 & & & & 5.52 & 1.225 & .783 \\
\hline Promoting my future income level & .787 & & & & 4.63 & 1.484 & .800 \\
\hline Enriching my work experience & .786 & & & & 5.02 & 1.379 & .773 \\
\hline Enhancing my critical thinking & .785 & & & & 5.63 & 1.145 & .726 \\
\hline Increasing my chances of getting a good job & .781 & & & & 4.97 & 1.476 & .760 \\
\hline Helping my future career development & .692 & & & & 5.32 & 1.340 & .794 \\
\hline Promoting my English communication skills & .637 & & & & 5.78 & 1.102 & .678 \\
\hline $\begin{array}{l}\text { Competition: } \\
\text { Being more insightful than others }\end{array}$ & & .831 & & & 5.15 & 1.276 & .818 \\
\hline Finding more solutions than others & & .784 & & & 5.05 & 1.293 & .797 \\
\hline Being the first to identify the key issues & & .782 & & & 5.02 & 1.357 & .763 \\
\hline Being the first to figure out a solution & & .765 & & & 4.96 & 1.343 & .786 \\
\hline Making more accurate judgment than others & & .666 & & & 5.15 & 1.351 & .588 \\
\hline Outperforming the other teams & & .623 & & & 4.74 & 1.327 & .728 \\
\hline Solutions more favored by the instructor & & .618 & & & 4.86 & 1.310 & .514 \\
\hline $\begin{array}{l}\text { Intrinsic Motivation: } \\
\text { Great fun to study English cases }\end{array}$ & & & .735 & & 4.44 & 1.448 & .843 \\
\hline Having great interest & & & .711 & & 4.86 & 1.348 & .810 \\
\hline Fond of the challenging tasks & & & .682 & & 4.63 & 1.413 & .816 \\
\hline Being impressed with the real events & & & .656 & & 4.72 & 1.443 & .751 \\
\hline $\begin{array}{l}\text { Self-efficacy: } \\
\text { To identify the key issues in the case }\end{array}$ & & & & .844 & 3.50 & 1.754 & .794 \\
\hline To solve the problems in the case & & & & .843 & 3.84 & 1.619 & .846 \\
\hline To figure out alternative solutions & & & & .730 & 4.22 & 1.513 & .777 \\
\hline To communicate clearly in English & & & & .552 & 4.44 & 1.402 & .682 \\
\hline
\end{tabular}


Extraction Method: Principal Component Analysis.

Rotation Method: Varimax with Kaiser Normalization.

a. Rotation converged in 7 iterations.

Loadings less than .53 are not presented for the sake of clarity.

\section{Competition Factor}

The second component is named Competition which measures the learner's desire to win and their satisfaction from improving their competence and abilities. This factor is constructed by 7 items with factor loadings ranging from 0.83 to 0.64 . All the items in the group fall into two categories: indirect competition items and direct competition items. In terms of the indirect competition items, "I want to be more insightful than others" and "I want to make more accurate judgment than others" share the same means of 5.15. The item "I want to find more solutions than others" receives the mean value of 5.05 and "I hope that my solution will be more favored by the instructor" 4.86 . The high means in this group suggest that the indirect competition is more likely to drive learners to be mastery-oriented (Elliott \& Dweck 1988), which implies that learners focus on increasing their competence instead of their performance when confronted with challenging tasks in the case studies. Interestingly, as an external source of their competence information, the Chinese ESP learners not only seek competence feedback from peer comparison but positive evaluation from the instructor who is, in this context, actually perceived as an authority who assesses their capabilities or an employer who offers the job opportunity.

The three variables "I want to be the first to identify the key issues (means 5.02)", "I want to be the first to figure out a solution (means 4.96)", and "I hope that my team will outperform any other teams (means 4.74)" measure more aggressive direct competition that reveals the desire to win. This propensity to outperform others might be well explained by the Chinese learners' awareness of insufficient job opportunities due to the fact that China has the world's largest population and the unprecedented number of college graduates seeking employment. This perception of China as a country of scarce resources, which is likely to be internalized, greatly enhances one's desire to win or fight for limited opportunities. For another reason, the majority of ESP learners in China are from business and law schools where the students have always been taught and trained to develop the perception of the BUSINESS IS WAR metaphor (Ling 2010). Deutsch (1962) suggested that many activities in the real world involve competitive elements. As a result, the reinforced desire to win plays a key role in motivating individuals to learn and grow competitive by increasingly committing themselves to specific learning activities, which helps them to survive the ubiquitous competition in the real world. The results suggest that the Competition dimension is identified as a main motivational factor in the case method applied to the Chinese ESP classrooms.

\section{E. Intrinsic Motivation Factor}

The third factor is named IM (Intrinsic Motivation) which investigates the learners' propensity to learn out of curiosity, interest, fun, and their autonomous actions. The component is represented by 4 items with a range of loadings from 0.74 to 0.66. Items "I think it is great fun to study English business cases" and "I have great interest in studying English business cases" are on top of the group, indicating that studying cases appeals to the Chinese ESP learners and they get actively engaged in the learning activity. The results suggest that the Chinese ESP learners are in want of training in terms of critical thinking, problem solving, decision making, and real-life challenges, all of which are the appealing elements of the case method. The constructivism nature of the case method satisfies the learning needs and develops autonomy of the ESP learners who get actively engaged in the learning activity and believe that they are being better prepared for the challenges they will face in the real world as managers, decision-makers and leaders. Perceived competence theory (Harter 1982; White 1959) assumes that learners are attracted to engage in learning activities where they feel competent. But Deci \& Moller (2005:583) argue that "competence is essentially a by-product in terms of people's intentions; it develops as they do what they find interesting and fun".

The Chinese ESP learners find studying cases interesting most probably because the case method involves constructivism and engaging elements that target advanced learners whose autonomy need as independent self-initiated learners and decision-makers is highly respected and fully satisfied. According to Little (1991:4), learner autonomy is "essentially a capacity for detachment, critical reflection, decision-making, and independent action; it presupposes that the learner will develop a particular kind of psychological relation to the process and content of learning". In light of this definition, the case method fosters an autonomy-supportive learning environment or situation where the learner's psychological relation to the learning activity is established and the learners take initiative or autonomous actions to be engaged in the learning process, independent from the control of others.

\section{F. Self-efficacy Factor}

The last core factor is named Self-Efficacy which measures the Chinese ESP learners' beliefs in their capabilities to complete learning tasks. The component consists of 4 items with loadings ranging from 0.84 to 0.55 . The most highly loaded items are "I think I can identify the key issues in the case" and "I think I can solve the problems in the case". The results suggest that the Chinese ESP learners have a strong sense of efficacy in studying business cases, as shown in their confidence that they have the capabilities to accomplish the challenging tasks involved in the learning activity.

As previously noted, modeling plays a key role in strengthening one's self-efficacy. The case method is likely to 
create an ideal learning environment offering such an indirect experience and a scenario where one's self-efficacy increases due to the fact that learners have the opportunities to observe and witness someone similar to them succeeding in solving real-world problems. This indirect experience arouses the feeling and awareness that "if they can do it, I can do it as well". Competent peers or models are likely to empower the learners to be mastery-oriented since interacting and communicating with these models provides more competence information. The development and acquisition of their skills and strategies in solving real business world problems will contribute to the learners' mastery experiences. When mastery successes build up, the sense of achievement will be the most effective way to establish and increase the learners' self-efficacy. On the other hand, the autonomy-supportive learning situation created by the case method is likely to generate the confident emotional state or optimistic mood, which affects the learners' judgments of efficacy in a positive way.

The self-efficacy factor indicates the Chinese ESP learners' beliefs in their capabilities to identify and solve problems, which determines the level of engagement and how much efforts they intend to make in case studies. The stronger the sense of efficacy, the higher level of involvement the learners will demonstrate and the more efforts they will intend to expend on the current learning activity.

\section{CONCLUSION}

A four-factor construct has been identified concerning the motivational effects of the case method on the Chinese ESP learners from both the macro and micro perspectives of SLA motivation: extrinsic motivation, intrinsic motivation, competition, and self-efficacy. First, the data analysis results suggest that the case method applied to ESP programs is a mixture of extrinsic and intrinsic motivation. Instrumentality, which proves to be universal in L2 learning motivation, plays a critical role especially in the learning and educational settings where utilitarianism philosophies prevail and demographic pressures shrink the amount of resources and opportunities available to the average person. The case method was also found to promote the learners' intrinsic motivation by fostering an autonomy-supportive L2 learning environment because it involves such engaging elements as real-life problem solving situations that most likely arouse great interest or curiosity of the advanced learners. Secondly, the competition factor involved in the case method was found to have a significant impact on the Chinese ESP learners' motivation due to the fact that competition in this situation integrates the learning and performance goals. The propensity to compete for limited resources equally helps it act as a key motivational factor in China's learning groups and communities. Thirdly, the Chinese ESP learner's strong self-efficacy indicated by their beliefs in their capabilities to solve problems highly validates the motivational effects of the case method. The mastery experiences and modeling involved in the case method are likely to contribute to the individual learners' strong sense of efficacy.

This study serves as an attempt to investigate the learner's motivational factors involving the case method in L2 settings, which may shed light on a better understanding of the learning motivation involved in Chinese ESP programs and the motivational components concerning country-specific socio-cultural factors. Due to the complexity and multifaceted nature of L2 learning motivation, the current research has many limitations in terms of its scope, sample size, and subject selection. Future researchers are suggested to extend the research scope, increase the sample size, and target non-business majors or English majors to test the validity and reliability of the motivational effects of the case method in ESP programs and other L2 settings.

\section{ApPendix. Questionnaire on the CASE Method Used in the ESP Programs (Translated)}

Dear students,

We are an English for Specific Purposes (ESP) teaching research team from Guangdong University of Foreign Studies investigating the effects of the case method employed in the ESP program. We really appreciate your response to the questionnaire. Please feel free to select a score for each item at your first thought and the score itself does not concern any issue of right or wrong. This questionnaire is anonymous and does not intend to collect personal information. All the data gathered in the survey shall be kept confidential and be used only for academic purposes. Thank you.

Notes: 1=totally disagree, $2=$ =strongly disagree, 3=disagree, 4=I don't know, 5=agree, $6=$ strongly agree, $7=$ totally agree

1. I think it is great fun to study English business cases. ( )

2. I think studying English business cases is beneficial to my career development. ( )

3. I am deeply impressed with the real events involved in the English business cases. ( )

4. I am fond of the challenging tasks involved in the English business cases. ( )

5. I am greatly interested in studying English business cases. ( )

6. I think studying English business cases shall increase my chances of finding a good job. ( )

7. I think studying English business cases shall enhance my competitive edge in the job market. ( )

8. I think studying English business cases shall enhance my critical thinking. ( )

9. I think studying English business cases shall expand my business expertise. ( )

10. I want to be more insightful than others in English case studies. ( ) 
11. I want to figure out more solutions than others. ( )

12. I think I can identify the key issues in any English business cases. ( )

13. I think I can figure out solutions to the problems. ( )

14. I want to be the first to identify the key issues. ( )

15. I want to be the first to figure out a solution to the problem. ( )

16. I hope that our team will outperform any other teams. ( )

17. I think studying English business cases can promote my future income level. ( )

18. I think studying English business cases shall improve my English communication skills. ( )

19. I think I can figure out alternative solutions. ( )

20. I think I can communicate my ideas clearly in English. ( )

21. I want to make more accurate judgment than others. ( )

22. I hope that my solution will be more favored by the instructor. ( )

23. I think studying English business cases can enrich my work experience. ( )

\section{ACKNOWLEDGEMENTS}

This research work was supported by the Chinese Scholarship Council (grant number: CSC 201807150009) and Guangdong University of Foreign Studies (grant number: GWJY2017045).

\section{REFERENCES}

[1] Ames, C. (1992). Classrooms: Goals, Structures, and Student Motivation. Journal of Educational Psychology, 84(3), 261-271.

[2] Bandura, A. (1977). Self-efficacy: Toward a Unifying Theory of Behavioral Change. Psychological Review, 84(2), 191-215.

[3] Bandura, A. (1982). Self-Efficacy Mechanism in Human Agency. American Psychologist, 37(2), 122-147.

[4] Bandura, A. (1994). Self-efficacy. In Ramachaudran, V.S. (Ed.), Encyclopedia of human behavior (Vol. 4, 71-81). New York: Academic Press.

[5] Brown, H.D. (2001). Teaching by Principles: an Interactive Approach to Language Pedagogy. (2nd Edition), 78-82, NY: Longman

[6] Business Information: Macro Policy. Information Technology and Informatization, 2019(2), p. 5

[7] Chen, B. (2014). The Questions, Methods, and Trends of ESP Research: Review of the Handbook of English for Specific Purposes Research. English Language Education, 35 (3), 110-113.

[8] Csizér, K \& Z. Dörnyei (2005). The Internal Structure of Language Learning Motivation and its Relationship with Language Choice and Learning Effort. The Modern Language Journal, 89, 19-36.

[9] Deci, E. L., \& A.C. Moller (2005). The Concept of Competence: A Starting Place for Understanding Intrinsic Motivation and Self-Determined Extrinsic Motivation. In: A. J. Elliot \& C. S. Dweck (Eds.), Handbook of competence and motivation, NY: Guilford Publications, 579-597

[10] Deci, E. L., Betley, G., Kahle, J., Abrams, L. \& J. Porac. (1981). When Trying to Win: Competition and Intrinsic Motivation. Personality and Social Psychology Bulletin, 7(1), 79-83.

[11] Deci, E., \& Ryan R.M. (1985). Intrinsic Motivation and Self-Determination in Human Behavior. Berlin: Springer Science \& Business Media.

[12] Deutsch, M. (1962). Cooperation and Trust: Some Theoretical Notes. In M. R. Jones (Ed.), Nebraska Symposium on Motivation, Lincoln, NE: University of Nebraska Press, 275-319.

[13] Dörnyei, Z. (1994). Motivation and Motivating in the Foreign Language Classroom. Modern Language Journal, 78, $273-284$.

[14] Dörnyei, Z. (1998). Motivation in Second and Foreign Language Learning. Language Teaching, 31(3), 117-135.

[15] Dörnyei, Z. (2005). The Psychology of the Language Learner: Individual Differences in SLA. Mahwah, New Jersey: Lawrence Erlbaum Associates, Inc.

[16] Elliott, E. S., \& C.S. Dweck (1988). Goals: An approach to motivation and achievement. Journal of Personality and Social Psychology, 54(1), 5-12.

[17] Epstein, J., \& Harackiewicz, J. (1992). Winning is Enough: the Effects of Competition and Achievement Orientation on Intrinsic Interest. Personality and Social Psychology Bulletin, 18, 128-139.

[18] Franken, R.E. \& D.J. Brown. (1995). Why do people like competition? The Motivation for Winning, Putting Forth Effort, Improving one's Performance, Performing Well, Being Instrumental, and Expressing Forceful/Aggressive Behavior. Personality and Individual Differences, 19(2), 175-184.

[19] Gardner, R.C. (1983). Learning Another Language: a True Social Psychological Experiment. Journal of Language and Social Psychology, 2, 219-239

[20] Gardner, R.C., \& W.E. Lambert. (1959). Motivational Variables in Second-Language Acquisition. Canadian Journal of Psychology, 13, 266-272.

[21] Harackiewicz, J., \& Manderlink, G. (1984). A Process Analysis of the Effects of Performance-contingent Rewards on Intrinsic Motivation. Journal of Experimental Social Psychology, 20, 531-551.

[22] Harter, S. (1982). The Perceived Competence Scale for Children. Child Development, 53, 87-97.

[23] Hmelo-Silver, C.E. (2004). Problem-based Learning: What and How do Students Learn. Educational Psychology Review, 16, 235-266.

[24] Hua, H. (1998). A Review of Research on English Learning Motivation and Strategies. Foreign Language World, 71 (3), 44-47.

[25] Ji, P. (2017). ESP Curriculum Design Based on the Guidelines of College English Teaching. Foreign Language World, 180 (3), $16-21$ 
[26] Jing, Yijia. (2017). Transformation of Chinese Governance: Pragmatism and Incremental Adaptation. Governance, $30,37-43$.

[27] Kurz, T., G. Llama, \& W. Savenye, (2005). Issues and Challenges of Creating Video Cases to Be Used with Perspective Teachers. TechTrends, 49(4), 67-73.

[28] Lamb M., \& Budiyanto. (2013). Cultural Challenges, Identity and Motivation in State School EFL. In: Ushioda E. (ed.) International Perspectives on Motivation: Language Learning and Professional Challenges. London: Palgrave Macmillan.

[29] Lamb, M. (2004). Integrative motivation in a globalizing world. System, 32 (1), 3-19.

[30] Lamb, M. (2012). A Self System Perspective on Young Adolescents' Motivation to Learn English in Urban and Rural Settings. Language Learning, 62(4), 997-1023.

[31] Lambert, W. E. (1973). Culture and Language as Factors in Learning and Education. Paper presented at the Annual Learning Symposium on "Cultural Factors in Learning" (5th, Western Washington State College, Bellingham, Washington, November 1973)

[32] Ling, S. (2010). A Cognitive Study of War Metaphors in Five Main Areas of Everyday English: Politics, Business, Sport, Disease and Love. PhD Thesis, Kristianstad University, Sweden, 12-14

[33] Little, D. (1991). Learner Autonomy: Definitions, Issues and Problems. Dublin: Authentik.

[34] Lunmani, M. (1972). Motivation to Learn a Second Language and Second Language Proficiency. Language Learning, 7 , 261-73.

[35] Meng, X. (2018). Current Employment Situation of College Graduates and the Key Issues. China Labor, 5, 4-13

[36] Merseth, K. (1991). The Early History of Case-Based Instruction: Insights for Teacher Education Today. Journal of Teacher Education, 42(4), 243-249.

[37] Noels, K.A., L.G. Pelletier, R. Clement, \& R.J. Vallerand (2003). Why Are You Learning a Second Language? Motivational Orientations and Self-Determination Theory. Language Learning, 53(S1), 33-64.

[38] Norman, G.R. \& H.G. Schmidt (1992). The Psychological Basis of Problem-based Learning: A Review of the Evidence. Academic Medicine, 67(9), 557-565

[39] Ramage, K. (1990). Motivational Factors and Persistence in Foreign Language Study. Language Learning, 40, 189-219.

[40] Ryan, R. M. \& J. P. Connell (1989). Perceived Locus of Causality and Internalization: Examining Reasons for Acting in Two Domains. Journal of Personality and Social Psychology, 57, 450-61

[41] Ryan, R.M. \& E.L. Deci (2000). Intrinsic and Extrinsic Motivations: Classic Definitions and New Directions. Contemporary Educational Psychology, 25, 54-67

[42] Shulman, L. (1992). Toward a Pedagogy of Cases. In J. H. Shulman (Ed.), Case Methods in Teacher Education. 1-30. New York: Teachers College Press

[43] Spencer, J. \& R. Jordan (1999). Learner Centered Approaches in Medical Education. British Medical Journal, 318, 1280-1283

[44] Tauer, J., \& Harackiewicz, J. (1999). Winning isn't Everything: Competition, Achievement Orientation, and Intrinsic Motivation. Journal of Experimental Social Psychology, 35, 209-238.

[45] Tripathi, K. N. (2001). Competition and Intrinsic Motivation. The Journal of Social Psychology, 132(6), 709-715.

[46] Ushioda, E. (1996). Learner Autonomy: The Role of Motivation. Dublin, Ireland: Authentik, 1-2

[47] Vallerand, R. J., Blais. M. R., Briere, N. M., \& L. G. Pelletier. (1989). Construction and Validation of the Academic Motivation Scale. Canadian Journal of Behavioral Science, 21, 323-49.

[48] Vallerand, R.J., L.G. Pelletier, M.R. Blais, N.M. Briere, C. Senecal, E.F. Vallieres. (1993). On the Assessment of Intrinsic, Extrinsic, and Amotivation in Education: Evidence on the Concurrent and Construct Validity of the Academic Motivation Scale. Educational and Psychological Measurement, 53, 159-172.

[49] Vallerand, R.J., Pelletier, L.G., Blais, M. R., Briere, N. M., Senecal, C., \& E. F. Vallieres. (1992). The Academic Motivation Scale: A Measure of Intrinsic, Extrinsic, and Amotivation in Education. Educational and Psychological Measurement, 52, 1003-1017.

[50] Wang, S. (2016). Interpreting the Key Points of the Guidelines on College English Teaching. Foreign Language World, 174 (3), $2-10$

[51] White, R. W. (1959). Motivation Reconsidered: The Concept of Competence. Psychological Review, 66, 297-333.

[52] Williams, M. \& R. L. Burden. (1997). Psychology for Language Teachers: A Social Constructivist Approach. Cambridge: Cambridge University Press, 120-141

[53] Yue, C. \& L. Zhou. (2017). A Trend Study on the Chinese University Graduates Employment: 2003 - 2017. Peking University Education Review, 15(4), 87-106

Zhiqiang Yu currently lectures at School of English and Education, Guangdong University of Foreign Studies, China. His research interests involve foreign language learning motivation, pragmatics and discourse analysis. And he has conducted a range of teaching research into English for Specific Purposes (ESP), L2 learning motivation, and discourse analysis. His recent publications are mainly with Chinese academic journals. 